\title{
Upaya Penanganan Tingkat Perdagangan Satwa Liar oleh Pemeritah Indonesia Pada Tahun 2013-2016
}

\author{
Ani Khoirunnisa, Pricille \\ Universita 17 Agustus 1945 Jakarta \\ aniejubaidi@gmail.com
}

\begin{abstract}
Wildlife trade is a wild trade in protected animals without regard to the existing rules. Some people are still buying and selling animals protected illegally, both buying and selling transactions that are alive to be maintained, or in the form of animals that have been preseerved. In fact, the trade in these animals has caused considerable losses for Indonesia. This wildlife trade cae is not carried out only by individuals but there is an organized as consumers of every product from wild animals. Therefore one of the efforts made by Indonesia is to conduct various international collaborations, because in responding to the case of wildlife trade, it is not enough only from law enforcement, and involving more than one country, international coopeeration is needed.The research method that writer used is a qualitative method with a descriptive type of research approach that is by describing phenomenas that occur to find out the efforts of the Indonesia government in handling the level of wildlife trade in the period 2013-2016. With the cooperation efforts carried out by the Indonesia government to help cover the shortcomings and constraints faced by the Indonesian government regarding the lack of human resources and also substantial financial resources to overcome the practice of wildlife trade.
\end{abstract}

Keywords: Wildlife Trade, Green Politics, International Cooperation, International Organizations

\section{Pendahuluan}

Keanekaragaman satwa yang merupakan bagian dari kekayaan alam yg penting bagi manusia, dapat dikelompokkan kedalam dua golongan yaitu satwa yang dilindungi dan tidak dilindungi. Sekalipun tiap negara memiliki kekhasannya satwanya masing-masing spt Komodo di Indonesia, beruang gizly dari Alaska. Indonesia memiliki sekitar 17\% jenis satwa liar atau sebesar 300.000 jenis satwa liar di dunia yang dapat ditemukan di Indonesia, dan diantaranya ada sekitar 816 jenis satwa endemik yang merupakan satwa yang keberadaannya sangat penting untuk dilindungi, sebab apabila satwa-satwa endemik ini punah maka 
keberadaannya tidak hanya punah di Indonesia melainkan di seluruh dunia (ProFauna, 2016) Namun saat ini keberlangsungan satwa-satwa tersebut terancam karena adanya perdagangan satwa liar secara ilegal.

Sebagian oknum masyarakat masih melakukan transaksi jual beli satwa dilindungi seacara ilegal baik transaksi jual beli dalam keadaan hidup untuk dipelihara, maupun dalam bentuk hewan yang sudah diawetkan. Sesungguhnya perdagangan satwa ini memberikan kerugian yang cukup besar bagi Indonesia, hal ini dikuatkan dari data yang dikutip dari tempo.com, Malang dikatakan bahwa "Indonesia mengalami kerugian hingga 9 triliun rupiah dari perdagangan Satwa liar dilindungi dan lemahnya penegakkan hukum terhadap para pelaku pada tahun 2009 hingga 2015” (Purmono, 2016). Praktek perdagangan satwa ilegal tersebut terus berlanjut hingga tahun 2017. Praktek tersebut banyak di temukan di pasar-pasar hewan, dan sangat disayangkan karena beberapa oknum tertentu yang melakukan perdagangan satwa liar ini memanfaatkan organ tubuhnya untuk dikonsumsi dan dijadikan sebagai bahan obat tradisional yang belum tentu benar faktanya, digunakan sebagai aksesoris pelengkap penampilan, sebagai pajangan, dsb. Berdasaarkan data yang diperoleh dari BBC Indonesia, untuk kasus perdagangan satwa liar sejauh ini melibatkan negara-negara lain tidak hanya Indonesia sebagai negara pengekspor. Beberapa negara pelanggar perdagangan satwa liar berasal dari Jepang, Cina, Vietnam, Thailand pada tahun 2012 (Indonesia B. , 2012). Menanggapi masalah yang cukup serius tersebut, pemerintah Indonesia melakukan upayaupaya mengatasi perdagangan satwa liar yang hampir setiap tahunnya mengalami kenaikan, dan untuk melindungi satwa langka dari kepunahaan. Kasus perdagangan satwa liar ini tidak dilakukan hanya perorangan melainkan adanya jaringan di dalamnya yang sifatnya terorganisir. Kasus perdagangan satwa liar juga turut melibatkan negara lain sebagai konsumen setiap produk-produk dari satwa liar. Maka dari itu salah satu bentuk upaya yang dilakukan Indonesia yaitu melakukan berbagai kerjasama internasional, karena dalam menanggapi kasus perdagangan satwa liar ini tidak cukup hanya dari penegak hukum saja, dan melibatkan lebih dari satu negara maka kerjasama internasional sangatlah dibutuhkan.

Beberapa upaya yang dilakukan oleh Pemerintah Indonesia dalam mengatasi perdagangan satwa liar yaitu Indonesia meratifikasi Convention on International Trade in 
Endangered Species of Wild Fauna and Flora (CITES) merupakan perjanjian internasional antar negara yang disusun berdasarkan resolusi pada sidang anggota World Conservation Union (IUCN) tahun 1963 (Batara, 2014, hal. 7-8). Karena CITES merupakan sebuah rezim internasional yang tidak memiliki kekuasaan penuh dalam kebijakan domestik dan perilaku suatu negara, maka dari itu keberhasilan dari CITES ini tergantung dari tingkat kepatuhan negara-negara anggota terhadap ketentuan-ketentuan CITES. Bentuk kerjasama lainnya yang dilakukan oleh pemerintah Indonesia dalam menangani perdagangan satwa liar yaitu melalui kerjasama dengan negara - negara di ASEAN yang dikenal dengan Asean Wildlife Enforcement Network (ASEAN). Kerjasama internasional dalam kasus perdagangan satwa liar sangatlah penting sebab kasus ini tidak hanya melibatkan satu negara saja melainkan antar negara dan juga mengenai adanya pertukaran informasi dalam keberlangsungan penyelidikan. Didalam suatu kerjasama tentunya dibutuhkan mitra baik itu negara pendukung ataupun organsisasi yang turut serta dalam kerjasama tersebut. Tentunya dalam kerjasama internasional akan ditemukan kendala - kendala yang akan dihadapi seperti hukum yang berlaku di setiap negara, penyatuan definisi serta kerjasama ekstradisi yang dilakukan (Atmasasmita, 2007), dan dibutuhkan tolak ukur keberhasilan yang tertulis dalam Role of Procedure (Amelinda, 2013). Masalahan perdagangan satwa liar tentunya berkaitan dengan masalah lingkungan dan alam dimana manusia masih sangat begantung pada hal ini. Masalah yang akan dibahas dalam tulisan ini adalah "Bagaimana upaya pemerintah Indonesia dalam penanganan penurunan perdagangan satwa liar”.

\section{Kerangka Konseptual}

\section{Green Politics}

Semakin meningkatnya jumlah penduduk dunia beberapa negara-negara barat mempercayai bahwa aktifitas ekonomi dan sosial manusia berjalan dengan cara yang mengancam lingkungan. Jumlah pendudukan dunia yang semakin meningkat yang mengejar standar hidup lebih tinggi adalah ancaman potensial bagi lingkungan. Oleh karenya dibutuhkan tindakan untuk mempertahankan lingkungan. Sebab, pertumbuhan jumlah penduduk dunia saat ini kian pesat dan tentunya pendapatan per kapita juga semakin meningkat. Di sisi lain, semakin rusaknya sistem lingkungan serta berkurangnya sumber daya 
alam, merusak sendi-sendi dasar bumi untuk mampu bertahan hidup (Apriwan, 2011, hal. 36). Dengan sendirinya, bumi tidak mampu lagi menampung semua tuntutan ekologi yang kian meningkat. Pertumbuhan apapun yang tanpa batas tidak akan dapat dilestarikan dengan sumber daya yang terbatas. Inilah ikatan yang sangat kuat dari posisi kurang menguntungkan bagi lingkungan hidup. Kepunahan spesies dan hilangnya keanekaragaman hayati merupakan salah satu permasalahan lingkungan yang dihadapi umat manusia, selain permasalahan pencemaran dan bencana lingkungan (Himawan, 2012). Menurut Soemarwoto dalam bukunya bahwa inti permasalahan lingkungan hidup adalah hubungan makhluk hidup, khususnya manusia, dengan lingkungan hidupnya (Soemarwoto, 2004). Lebih lanjut Soemarwoto mengatakan ilmu yang mempelajari hubungan timbal balik makhluk hidup dan lingkungan hidupnya disebut ekologi. Oleh karena itu, permasalahan lingkungan hidup pada hakekatnya adalah permasalahan ekologi.

Hubungan timbal balik dan interaksi yang terjadi tersebut akan membentuk suatu kesatuan sistem ekologi yang teratur yaitu ekosistem. Keteraturan itu terjadi oleh adanya transfer energi dan materi antar komponen dalam bentuk rantai makanan dan jaring-jaring makanan. Kehilangan atau berkurangnya salah satu komponen akan menyebabkan sistem tersebut terganggu atau mengalami ketidakseimbangan (Himawan, 2012). Perlindungan atau konservasi terhadap jenis satwa maupun tumbuhan merupakan hal yang sangat penting untuk menjaga keseimbangan ekosistem dan daya dukung lingkungan hidup. Selain untuk menjaga keseimbangan ekosistem, tumbuhan dan satwa juga bermanfaat sebagai sumber genetik. Setiap makhluk hidup memiliki keanekaragaman genetik, sehingga setiap jenis memiliki sifat keturunan yang tertentu. Praktek perdagangan satwa liar dan tumbuhan ilegal merupakan salah satu bentuk dari kejahatan terhadap lingkungan (enviromental crime). Sesuai dengan pengertian yang dikembangkan oleh United Nation Interregional Crime and Justice Research Institute, bahwa kejahatan terhadap lingkungan terdiri dari 5 bentuk kejahatan, antara lain (UNICRI, 1991) :

a. Perdagangan ilegal tumbuhan dan satwa liar yang melanggar konvensi internasional tentang perdagangan species flora dan fauna yang terancam punah (Convention on Internasional Trade in Endangered Species of Wild fauna and flora). 
b. Perdagangan ilegal Ozones-Depleting Substances ( ODS ) yang melanggar Protokol Montreal 1987.

c. Pembuangan dan pengangkutan ilegal limbaah berbahaya.

d. Ilegal fishing

e. Ilegal logging

Negara bukanlah satu-satunya yang memiliki kekuatan untuk menangani permasalahan lingkungan. Negara haruslah mengambil perannya dengan bekerjasama dengan negara lain untuk menangani isu lingkungan (Sorensen, 2014). Menurut Ronald Inglenghart (Apriwan, 2011, hal. 40), kehadiran the greens merupakan fenomena pasca-materialisme (post materialism) yang berargumen bahwa fenomena ini tidak bisa lepas dari adanya kecendrungan perubahan dalam masyarakat paska industri. Pada titik itu, terjadi pergeseran dari 'nilai-nilai kelangkaan' ke nilai-nilai 'pascamaterialis', dan sekaligus perubahan distribusi nilai-nilai yang tidak sesuai dengan jalur-jalur kelas seperti dikotomi kiri- kanan. Dengan mengumpulkan materi survei dari serangkain negara industri, Inglehart menunjukan bahwa nilai-nilai pencapaian dan pertumbuhan ekonomi memudar seiring meningkatnya kemakmuran, sehingga masyarakat memperlihatkan lebih besarnya sensivitas mereka akan isu kualitas hidup, yang menyangkut seperti lingkungan, niali-nilai kebebasan berekspresi dan partisipasi.

Politik Hijau merupakan isu baru dalam kamus politik kotemporer. Perkembangan gerakan politik ini tidak hanya muncul dan berkembang dalam fora politik nasional, tetapi sudah ikut berkembang dalam tingakat regional bahkan global (Apriwan, 2011, hal. 40).

Menurut Tim Hayward, perkembangan teori Politik Hijau (Green political theory) diambil dari fakta bahwa manusia merupakan bagian dari alam, sehingga yang memiliki implikasi bagi perilaku politiknya. Dengan argumen ini, teori politik juga harus selaras dengan teori-teori lingkungan. Artinya, manusia tidak hanya dilihat sebagai individu yang rasional (seperti dalam pandangan liberalisme) atau sebagai makluk sosial(seperti pandangan sosislisme) akan tetapi sebagai natural beings, dan lebih jauh sebagai political animals (Apriwan, 2011, hal. 41).

Krisis lingkungan hidup global yang tengah kita hadapi saat ini sebenarnya bersumber pada kesalahan pemahaman atau cara pandang manusia mengenai dirinya, alam, 
dan tempat manusia dalam keseluruhan ekosistem (Keraf, 2010, hal. 2). Inilah yang merupakan awal dari setiap bencana lingkungan hidup yang tengah kita alami saat ini. Kesalahan pemahaman ini bersumber dari etika antroposentrisme.

Antroposentrisme merupakan teori etika lingkungan yang memandang manusia sebagai pusat dari sistem alam semesta. Manusia dan kepentingannya dianggap yang paling menentukan dalam tatanan ekosistem dan dalam kebijakan yang diambil dalam kaitan dengan alam, baik secara langsung atau tidak langung. Yang memiliki nilai tertinggi adalah manusia dan kepentingannya. Segala sesuatu yang lain di alam semesta ini hanya akan mendapat nilai dan perhatian sejauh menunjang dan demi kepentingan manusia . Oleh karenanya alam pun hanya dilihat sebagai obyek, alat dan sarana bagi pemenuhan kebutuhan dan kepentingan manusia. Alam hanya alat bagi pencapaian tujuan manusia. Alam tidak mempunyai nilai pada dirinya sendiri (Keraf, 2010, hal. 47).

Didalam pemahaman etika antroposentris, manusia berkembang dalam interaksi dengan sesama manusia di dalam komunitas sosialnya menjadi dirinya sendiri. Identitas diri manusia dibentuk oleh komunitas sosialnya sebagaimana manusia itu sendiri ikut membentuk komunitas sosialnya. Manusia tidak dilihat sebagai makhluk ekologis yang identitasnya ikut dibentuk oleh alam (Keraf, 2010, hal. 3). Etika antroposentris ini memahami bahwa alam merupakan sumber hidup manusia. Etika ini menekankan hal-hal berikut ini (Apriwan, 2011) : Manusia terpisah dari alam, Mengutamakan hak-hak manusia atas alam tetapi tidak menekankan tanggung jawab manusi, Mengutamakan perasaan manusia sebagai pusat keprihatinannya Kebijakan dan manajemen sunber daya alam untuk kepentingan manusia, Norma utama adalah untung rugi, Mengutamakan rencana jangka pendek. Pemecahan krisis ekologis melalui pengaturan jumlah penduduk khususnya di negara miskin Menerima secara positif pertumbuhan ekonomi.

\section{Kerjama Internasional}

Seiring meningkatnya hubungan antar negara pada saat ini, dirasa sangat tepat menggunakan teori kerjasama internasional dalam bahsan ini. Tidak ada negara di dunia ini yang dapat berdiri sendiri dalam memenuhi kebutuhan terlebih dalam meningkatkan perkembangan dan kemajuan negaranya. Negara sebagai aktor utama dalam hubungan 
internasional untuk memenuhi kebutuhan rakyatnya membutuhkan kerjasama internasional. Menurut Charles H. Cooley, adalah jika seseorang menyadari dirinya mempunyai kepentingan yang sama dengan orang lain maka kerjasama pun dapat berlangsung (Maxmanroe, 2018). Kerjasama internasional dapat terbentuk karena adanya kebutuhan internasional yang meliputi bidang ekonomi, politik, sosial, lingkungan hidup, kebudayaan, pertahanan dan keamanan (Perwita, 2005, hal. 33) . Begitupun keberadaan kerjasama internasional sangatlah penting, karena kerjasama internasional memberikan wadah bagi para aktor untuk melaksanakan pola hubungan internasional melalui kooperasi dan kerjasama antar aktor. Sebuah hubungan kerjasama mampu bertahan lama namun juga dapat menimbulkan konflik karena adanya ketidakcocokan atau perselisihan di tengah jalan. Oleh karena itu, dibutuhkan komitmen agar kerjasama ini dapat bertahan dan terlaksana dengan baik.

Menurut Joseph Greico, kerjasama internasional berlangsung bila ada kepentingan objektif, dan bila kepentingan objektif ini berubah maka kerjasama pun dapat berakhir (Maxmanroe, 2018). Umumnya hubungan dan interaksi dalam bentuk kerjasama terjadi secara langsung diantara dua pemerintah dengan kepentingan atau masalah yang sama secara bersamaan, bentuk kerjasama yang dilakukan oleh negara bernaung dalam organisasi dan lembaga internasional (Baldwin, 1990). Ada beberapa alasan mengapa negara melakukan kerjasama dengan negara lainnya (Ardiaz, 2017):

a. Dengan alasan demi meningkatkan kesejahteraan ekonominya banyak negara yang melakukan kerjasama dengan negara lainnya untuk mengurangi biaya yang harus ditanggung negara tersebut dalam memproduksi suatu produk kebutuhan bagi rakyatnya karena adanya keterbatasan yang dimiliki negara tersebut.

b. Untuk meningkatkan efisiensi yang berkaitan dengan pengurangan biaya.

c. Karena adanya masalah-masalah yang mengancam keamanan bersama.

d. Dalam rangka mengurangi kerugian negatif yang diakibatkan oleh tindakan-tindakan individual negara yang memberi dampak terhadap negara lain.

Sifat kerjasama internasional biasanya bermacam macam, seperti harmonisasi hingga integrasi . Kerjasama seperti itu dapat terjadi jika ada dua kepentingan bertemu dan tidak ada pertentangan di dalamnya (Brian Hocking, 1990). Ketidakcocokan antara negara-negara atau 


\section{Global Insight Journal}

pihak-pihak yang terlibat dalam kejasama tersebut tentunya pasti akan ada tetapi dapat ditekan oleh adanya kerjasama tersebut.

Ada dua tipe dasar yang coba dipecahkan dari kerjasama internasional ini. Tipe pertama mencakup kondisi-kondisi lingkungan internasional yang apabila tidak diatur maka akan mengancam negara-negara yang terlibat. Tipe kedua mencakup keadaan sosial, ekonomi, dan politik domestik tertentu yang dianggap membawa konsekuensi luas terhadap system internasional sehingga dipresepsi sebagai masalah internasional bersama (Wiliam D Coplin, 1992). Oleh karena itulah kerjasama internasional amat dibutuhkan agar tercapainya kepentingan bersama. Kerjasama internasional tersebut terjadi dalam dua tingkatan, yaitu kerjasama bilateral yang hanya dilakukan oleh dua negara saja dan kerjasama multilateral. Seperti definisi kerjasama internasional menurut Coplin dan Marbun, "Kerjasama yang awalnya terbentuk dari satu alasan dimana negara ingin melakukan interaksi rutin yang baru dan akan lebih baik bagi tujuan bersama. Interaksi-interaksi ini sebagai aktifitas pemecahan masalah secara kolektif, yang berlangsung baik secara bilateral maupun multilateral" (Wiliam D Coplin, 1992).

\section{Analisis Dan Pembahasan}

Secara global, Menurut data PBB dan interpol bahwa perdagangan satwa liar di seluruh dunia mencapai 15 hingga 20 milliar dollar (ProFauna, 2016). Untuk praktek perdagangan satwa liar di Indonesia mencapai nilai sebesar Rp 13 triliun per tahun dan telah meningkat empat kali lipat terhitung sejak tahun 2010. Perdagangan satwa liar secara ilegal ini telah menjadi sebuah industri dan sindikat kriminal terbesar setelah narkotika (Ramadhani, 2015). Hal ini dikarenakan prosesnya yang dianggap tidak terlalu beresiko dan lebih menguntungkan daripada upaya perdagangan ilegal lainnya. Oleh karena itu diperlukan tindak lanjut secara khusus dari pemerintah khususnya Indonesia sebagai salah satu negara pemasok satwa dilindungi yang sangat berpotensi dalam industri ini.

\section{Politik Hijau \& CITES (Convention on International Trade in Endangered Species of Wild Fauna and Flora)}


Politik lingkungan yang lebih sering disebut politik hijau ( Green Politics ) mulai melakukan perubahan-perubahan. Gerakan yang pada awalnya hanya berbentuk gerakan aksi, mencoba melembagakan diri ke dalam bentuk partai politik. Asumsinya, gerakan aksi an sich tidak cukup untuk mempengaruhi proses pengambilan kebijakan. Sehingga, dibutuhkan institusi seperti partai politik yang bisa menjadi bagian pengambilan kebijakan di level nasional atau lokal ( stakeholder ) (Apriwan, 2011). Indonesia adalah negara kesatuan yang berdaulat dan akan selalu menjaga komitmen berbagai kesepakatan terhadap perjanjian hukum internasional, salah satunya dalam bidang perdagangan tumbuhan dan satwa liar. Konvensi pengendalian perdagangan spesies yang terancam punah yang digunakan adalah CITES (Convention on International Trade in Endangered Species of Wild Fauna and Flora). CITES adalah suatu perjanjian multilateral untuk menjawab salah satu faktor ancaman dari kepunahan spesies. CITES terbentuk pada tahun 1973 dan mulai berlaku 1975 (Cifebrima Suyastri, 2012). Karena kegiatan perdagangan satwa liar ini melintasi batas negara atau paling tidak melibatkan dua negara, usaha untuk membuat perjanjian internasional adalah jalan terbaik dengan terbentuknya CITES untuk melindungi spesies tertentu dari eksploitasi yang berlebihan.

\section{Kewajiban Negara-negara Anggota CITES}

Kewajiban Negara anggota terkait dengan CITES ialah pada intinya melaksanakan usaha-usaha dalam rangka memberlakukan ketentuan dalam CITES dan melarang pelaksanaan perdagangan spesimen yang bertentangan dengan konvensi (Batara, 2014). Usaha-usaha tersebut dapat dilaksanakan dalam bentuk memberikan hukuman terhadap perdagangan dan atau kepemilikan spesimen yang dilarang, serta menyediakan penyitaan atau pengembalian spesimen kepada negara ekspor. Selain itu, dalam Article VIII point 6 konvensi CITES pun menyatakan tanggung jawab setiap Negara anggota sebagai berikut (CITES, Article Convention On International Trade in Endangered of Wild Fauna and FLora, 1976, hal. 250) :

"Each Party shall maintain records of trade in specimens of species included in Appendices I, II and III which shall cover: (a) the names and addresses of exporters and importers; and $(b)$ the number and type of permits and certificates granted; the States with which such trade occurred; the numbers or quantities and types of 
specimens, names of species as included in Appendices I, II and III and, where applicable, the size and sex of the specimens in question."

Dijelaskan bahwa negara Anggota memiliki tanggungjawab untuk mencatat pelaksanaan perdagangan specimen yang ada dalam Appendix I, II, dan III serta memberikan laporan terkait dengan pengimplementasian CITES kepada Secretariat. Laporan tersebut dapat berbentuk:

a. Annual report, yang berisikan informasi terkait dengan jumlah transaksi perdagangan dan izin yang dikeluarkan.

b. Biennial report, terkait dengan usaha-usaha administratif serta legislated yang dilaksanakan oleh pemerintah dalam rangka mengimplementasikan Konvensi.

\section{CITES di Indonesia}

Pemerintah Republik Indonesia telah meratifikasi CITES pada Desember 1978, melalui Keppres No. 43 tahun 1978 mengenai ratifikasi CITES (List of Contracting Parties, 2018). Sebagai Negara yang telah meratifikasi CITES, Indonesia berkewajiban melaksanakan berbagai ketentuan CITES antara lain melarang perdagangan, mengenakan sanksi terhadap pelaku pelanggaran dan melakukan penyitaan terhadap specimen yang diperdagangkan tidak sesuai dengan ketentuan CITES. Namun harus diakui bahwa walaupun sudah diratifikasi dalam waktu yang cukup lama, tetapi peraturan CITES belum dapat diimplementasikan secara optimal untuk mendukung perdagangan tumbuhan dan satwa yang berkesinambungan. Dalam pengimplementasiannya CITES di Indonesia menunjukkan peningkatan yang cukup signifikan terutama dalam hal pelibatan para stake holders termasuk Lembaga Swadaya Masyarakat (LSM) mengenai isu CITES. Pengakuan otoritas Ilmiah dan otoritas pengelola (Management Authorithy) telah diperoleh oleh pihak LSM untuk berperan serta dalam pelaksanaan CITES yang sesuai dengan kapasitas dan fungsi yang dimiliki.

untuk dapat melihat apakah aturan-aturan tertulisnya telah diimplementasikan secara efektif atau tidak, menurut Juan Carlos Vaquue, CITES tersebut harus melakukan tiga tahap yaitu (Aristides. Yoshua, 2016): 


\section{a. Implementasi}

Suatu negara mengimplementasikan kewajiban-kewajiban CITES melalaui tiga Fase yang berbeda. pertama; dengan mengadopsi tindakan-tindakan implementasi nasional termasuk tindakan-tindakan legislatif dan ekonomi, system informasi, rencana manajemen, dan unit pelaksana hukumnya, kedua; memastikan tindakan-tindakan nasional telah terpenuhi sesuai dengan yang ada di dalam wilayah yuridiksi dan kendali, ketiga; memenuhi kewajiban-kewajiban sekretariat CITES seperti, melaporkan volume perdagangan dan tindakan-tindakan (measure) yang dapat berpengaruh terhadap kewajiban internasionalnya (Aristides.Yoshua, 2016).

\section{b. Pemenuhan Kewajiban (compliance)}

Tahap ini memiliki dua dimensi, pada tingkat internasional berkaitan dengan apa yang telah dilakukan Negara anggota untuk memenuhi kewajibannya dengan obligasi yang ada di konvensi, dan pada tingkat nasional mengacu kelangkah-langkah yang diambil oleh individu atau entitas legal seperti korporasi dan agen-agen pemerintah untuk memenuhi kewajiban undang undang domestiknya (Aristides.Yoshua, 2016).

\section{c. Pelaksanaan hukum (enforcement)}

Dalam konteks CITES, pelaksanaan hukum adalah tindakan - tindakan yang diambil oleh Negara anggota untuk menghentikan atau menghambat perdagangan legal ini termasuk inspeksi untuk menentukan status dari pemenuhan kewajiban undang-undang dan mendeteksi legal yang diperlukan untuk memenuhi kewajiban dan menjatuhkan sanksi bagi yang melanggar aturan konvensi atau aturan nasional (Aristides. Yoshua, 2016).

\section{ASEAN Wildlife Enforcement Network (ASEAN-WEN)}

$A S E A N-W E N$ merupakan sebuah jaringan penegakan hukum antar pemerintah di regional ASEAN yang dibentuk untuk memerangi perdagangan hewan dan tumbuhan ilegal. Dan sebuah platform untuk melakukan kolaborasi regional antara lembaga penegak hukum nasional, CITES otoritas, Bea dan cukai, Polisi, Jaksa dan kelompok khusus penegakan satwa liar. WENs merupakan sebuah respon regional proaktif terhadap perdagangan satwa liar dan hilangnya spesies. Indonesia sebagai negara anggota yang juga turut berperan aktif dalam program kerjasama ASEAN-WEN seperti pada perjanjian ASEAN lainnya. 
Indonesia telah mengimplementasikan program dan kegiatan yang terkait dengan pemberantasan wildlife crime sebagaimana diungkapkan oleh National Project Manager Multidoor Project, UNDP Indonesia sebagai berikut (Amelinda, 2013) :

"Terlepas dari plus minusnya hal itu bahwa sudah adanya regulasi nasional yang dilakukan oleh Indonesia dalam upaya menekan perdagangan satwa liar ilegal dan beberapa program hasil kerjasama internasional"

Sejak pertama kali dibentuk sampai saat ini ASEAN WEN telah mengadakan pertemuan tahunan selama 7 (tujuh) kali. Indonesia selalu mengikuti dan berperan secara aktif dalam pertemuan-pertemuan tersebut, bahkan di tahun kedua Indonesia bertindak selaku tuan rumah. Dalam setiap pertemuan, tiap negara anggota melaporkan kegiatan dan capaian dalam upaya pemberantasan wildlife crime. Selain laporan dalam pertemuan tahunan tersebut, setiap triwulan juga diwajibkan melaporkan hasilhasil operasi penegakan hukum yang akan ditampilan di website $A S E A N$ WEN. Pertemuan ini juga dapat menjadi media pertukaran informasi tentang keberhasilan masing-masing negara anggota sehingga keberhasilan tersebut dapat diterapkan di masing-masing negara. Indonesia telah membentuk National Task Force berdasarkan Keputusan Direktur Jenderal PHKA selaku National Focal Point pada tahun 2008 Namun demikian pembentukan Task Force ini kurang berjalan efektif karena tidak semua anggota terlibat secara aktif, sehingga tujuan pembentukan Task Force untuk mensinergiskan upaya pemberantasan wildlife crime dari instansi terkait belum dapat tercapai.

\section{Kerjasama Indonesia dengan Organisasi Internasional}

\section{Coral Triangle Initiatives (CTI)}

Indonesia sebagai salah satu negara dengan keanekaragaman terumbu karang yang tinggi sadar bahwa perubahan iklim global akan berpengaruh besar terhadap keberadaan dari terumbu karang. Ditambah dengan faktor manusia yang membuat keberadaan terumbu karang semakin terancam. Dalam satu dekade terakhir sebenernya berkaitan dengan kerjasama dengan proteksi perdagangan satwa regional khusus untuk spesies laut ada CTI (Coral Triangle Inisiatif) merupakan Inisiatif yang dibangun pemerintah indonesia, brunai darusalam, philiphina, PNG, Malaysia,Timor Timur, dan kepulauan Solomon (Hanif, 2018). 
CTI merupakan bentuk tindak lanjut dari gagasan Presiden Susilo Bambag Yudhoyono yang disampaikan di sela-sela Convention on Biological Diversity (CBD) ke-8 di Brazil pada 2006 didasari kenyataan bahwa perairan Indonesia dan kawasan di sekitarnya merupakan habitat bagi highest level of coral diversity (setidaknya terdapat 5000 lebih jenis coral), sehingga dengan sendirinya memiliki kekayaan sumber daya hayati yang besar.

Peranan Indonesia didalam CTI mulai dari menindaklanjuti hasil-hasil dari CTI Summit di Manado, 15 Mei 2009, telah dilaksanakan SOM 4 di Kinabalu, November 2009 dimana telah disusun Term Of Reference (TOR) dari struktur organisasi CTI. MM 2 di Gizo, Solomon Island telah memutuskan Indonesia menjadi ketua dari Council of Minister CTI untuk periode 2010-2011 dan menjadi host dari Sekretariat Regional CTI. Selain itu Indonesia menjadi Chairman dari Coordination Mechanism Working Group (CMWG) yang menerima mandat dari Council of Minister untuk menyusun struktur organisasi Sekretariat Permanen CTI serta dokumen legal yang menyertainya dan Financial Mechanism Working Group (kemlu, 2018).

Perkembangan Kerjasama Coral Triangle Initiative (CTI) saat ini dalam proses pembentukan Permanent Secretariat Regional dan menyusun legal dokumen. Pada SOM 6 di Manado, November 2010 telah disepakati Agreement on Establishment of Permanent Secretariat Regional CTI beserta 3 (tiga) dokumen pendukung lainnya yaitu Rules of Procedure, Financial Regulation dan Staff Regulation. Keempat dokumen ini diharapkan dapat diadopsi pada Pertemuan Council of Minister ke-3 di Ambon pada tahun 2011 (kemlu, 2018).

\section{BIJAK (Bangun Indonesia untuk Jaga Alam Keberlanjutan)}

Kegiatan ini dibangun di atas komitmen negara-negara anggota ASEAN untuk memperkenalkan dan menegakkan hukum kejahatan satwa liar dan mempromosikan keterlibatan internasional dalam konservasi keanekaragaman hayati. Di Indonesia program BIJAK USAID bekerjasama dengan Change.org Indonesia dan memfasilitasi sebuah lokakarya dengan maksud untuk memahami dan meningkatkan kapasitas organisasi organisasi masyarakat sipil dan komunitas - komunitas dalam menggunakan media sosial untuk berbagi informasi, membuka ruang untuk terciptanya kanal baru komunikasi dan 
penyampaian pendapat publik serta bertukar gagasan terkait kampanye lingkungan dan konservasi di Indonesia. Beberapa tuujuan dari USAID Wildlife Asia adalah:

a. Mengurangi Permintaan Konsumen

Permintaan yang melonjak dan harga produk satwa liar yang menggiurkan mendorong penurunan drastis pada spesies seperti gajah, badak dan harimau. Melalui Kegiatan ini, USAID mengurangi permintaan ini dengan mengkomunikasikan, memobilisasi, dan mengadvokasi cara-cara untuk membangun norma sosial baru seputar penggunaan produk satwa liar. Intervensi termasuk kampanye perubahan perilaku yang ditargetkan menggunakan pemasaran sosial yang telah terbukti dan alat komunikasi perubahan sosial dan perilaku.

b. Memperkuat Penegakan Hukum Regional

USAID memperkuat lembaga penegak hukum regional untuk secara efektif menemukan, menangkap, dan menuntut pedagang satwa liar ilegal sekaligus memperbaiki kebijakan dan peraturan lingkungan untuk memerangi kejahatan terhadap satwa liar. USAID terlibat dengan pemerintah dan mitra Asia untuk membantu menyelaraskan undang-undang dan hukuman regional untuk kejahatan terhadap satwa liar, memperkuat hukum jika perlu dan mendukung hakim dan pengacara untuk membawa lebih banyak kasus ke pengadilan.

c. Mempromosikan Kerjasama Regional

USAID mendukung upaya ini di Asia dan Afrika, menyediakan platform regional untuk berbagi informasi, komunikasi, perencanaan dan mengadakan dukungan administratif lainnya. Tim USAID Wildlife Asia menerapkan metode berbasis bukti dan teknologi terbukti yang mendorong pengambilan keputusan kolaboratif yang efektif dan inisiatif inovatif di seluruh struktur regional yang terintegrasi. Ini dibangun di atas hubungan yang telah terjalin dalam pendekatan lintas sektoral lintas sektoral untuk mengakhiri kejahatan terhadap satwa liar di seluruh Kamboja, Cina, Laos, Indonesia, Thailand dan Vietnam.

\section{Sumatran Tiger}

Sumatran Tiger adalah proyek yang diimplementasikan di bawah kerangka UNDP Country Programme Action Plan (CPAP) 2011 - 2015. Kerangka ini menerapkan Modal Implementasi Nasional atau National Implementation Modality (NIM), dimana Kementerian 
Lingkungan Hidup dan Kehutanan berperan sebagai Mitra Pelaksana, yang bertugas dan bertanggung jawab untuk mengelola proyek - termasuk melakukan pengawasan dan evaluasi intervensi-intervensi proyek, pencapaian target dan penggunaan sumber daya proyek secara efektif (Tiger, 2018). Direktur Konservasi Keanekaragaman Hayati bertindak sebagai Direktur Proyek Nasional atau National Project Director (NPD), yang menjadi penghubung utama proyek dengan Kementerian Lingkungan Hidup dan Kehutanan. NPD bertanggung jawab untuk menyediakan fasilitas pemerintah dan panduan bagi implementasi proyek.

\section{Visi}

Dalam jangka panjang, solusi yang ditawarkan untuk menyelamatkan hutan, tumbuhan dan satwa liar, jasa ekosistem di Sumatera adalah melalui konsolidasi jaringan antar wilayah lindung yang didanai secara cukup dan dikelola secara efektif, disokong oleh aksi-aksi lain di komunitas dan sekitar hutan, guna mewujudkan pengelolaan lanskap secara berkelanjutan. Adapula hambatan utama guna mencapai visi program ini adalah kombinasi antara lemahnya kontrol atas sumber daya alam dan kapasitas tata kelola wilayah lindung, buruknya koordinasi antar lembaga serta kurangnya perencanaan pendanaan dan manajemen di wilayah-wilayah lindung.

\section{Misi}

Proyek Sumatran Tiger bertujuan untuk melindungi dan mempromosikan sistem pengelolaan yang berkelanjutan bagi wilayah dengan keanekaragaman hayati penting di Indonesia. Proyek ini bertujuan untuk memperbaiki praktik konservasi keanekaragaman hayati di sejumlah lanskap prioritas di Sumatra melalui penerapan praktik-praktik manajemen terbaik di kawasan lindung dan lanskap produksi di sekitarnya, menggunakan indikator pelestarian dan pemulihan habitat harimau sebagai indikator kesuksesan. Dalam Proyek sumatran tigers ini menyadari bahwa upaya pada masa lalu untuk mencapai tujuan tersebut di Sumatera terhambat oleh buruknya perencanaan kelembagaan serta lemahnya koordinasi dan kerja sama antara berbagai instansi pemerintah dan organisasi kemasyarakatan. Hal tersebut terjadi karena ketiadaan kerangka kerja yang efektif untuk berbagi informasi dan strategi pembangunan, masih terbatasnya bidang kolaborasi, serta lemahnya kapasitas dan keahlian kunci untuk melakukan aksi-aksi tersebut. 
Proyek ini bertujuan untuk mengatasi berbagai masalah kelembagaan, tata kelola dan finansial tersebut yang saat ini mencegah tercapainya target dari proyek. Proyek akan menciptakan model tata kelola keanekaragaman hayati yang didasarkan atas kemitraan antara pemerintah dan organisasi kemasyarakatan yang bisa diterapkan di semua target lanskap dan bisa disebarluaskan ke seluruh Sumatera dan jika memungkinkan ke seluruh Indonesia.

\section{Kendala - kendala yang dihadapi}

Dengan berbagai upaya yang telah dilakukan oleh Pemerintah Indonesia untuk mengatasi tingkat perdagangan satwa liar terlihat sudah sangat baik, namun dalam pelaksanaannya ada beberapa kendala yang dihadapi di Indonesia, di antaranya adalah Kurangnya Pemahaman mengenai CITES, Kurangnya Data Ilmiah Pendukung Kuota, Penegakan Hukum Belum Optimal, Kurangnya Kesadaran dan Faktor Ekonomi Masyarakat, Minimnya Sumber Daya Manusia.

\section{Kesenjangan dan Tantangan Utama}

Meskipun kerangka hukum untuk perlindungan satwa liar dan peraturan perdagangan satwa liar telah dikembangkan dengan baik, namun terdapat sejumlah celah yang besar, yang dapat memfasilitasi atau memungkinkan terus berjalannya perdagangan satwa liar yang dilindungi, dan spesies lain yang terancam di Indonesia.

a. Cakupan Hukum

Tantangan Utamanya yaitu PP No 7/1999 sudah usang dan lemah, sebagai turunan UU No. 5/1990, yang gagal untuk melindungi spesies yang terdaftar di CITES, dan spesies lain merupakan fokus pelestarian di Indonesia. Daftar spesies yang dilindungi disetujui oleh peraturan pemerintah (ditandatangani oleh Presiden) pada tahun 1999, dan tidak pernah diperbarui, meskipun telah ada ketentuan Pasal 4 dari peraturan yang memperbolehkan Menteri untuk mengubah daftar tersebut.

b. Deteksi dan Pelaporan 
. Deteksi yang dilakukan oleh pemerintah terbatas dan tidak punya cukup sumber daya. Deteksi sering dilakukan oleh organisasi non-pemerintah, seperti Wildlife Conservation Society (WCS), Fauna dan Flora International (FFI), Jakarta Animal Aid Network (JAAN), Profauna dan lainnya. Polisi Hutan/kemitraan dengan komunitas dapat menjadi salah satu sumber informasi, yang dapat ditingkatkan dan ditargetkan ke wilayah tertentu yang rentan (Wildlife Conservation Society, 2015).

\section{c. Penangkapan dan Penahanan}

Penangkapan hanya bisa dilakukan polisi. Proses hukum yang tidak benar seringkali terjadi setelah penangkapan atau penahanan, yang dapat berujung pada penghentian kasus pada tahap awal proses. Kurangnya pengetahuan teknis penyidik kepolisian dan jaksa penuntut. Penanpgkapan tidak dapat dilakukan tanpa surat perintah, dan tidak dapat berlangsung lebih dari 24 jam kecuali ancaman pidana yang dapat dikenakan lebih dari 5 tahun penjara.

\section{d. Pendaftaran Kasus dan Tuntutan}

Jaksa penuntut sering bermasalah dengan terbatasnya pengetahuan mengenai pilihan untuk memaksimalkan tuntutan untuk tersangka, dan pengetahuan teknis yang buruk terkait masalah perdagangan satwa liar memainkan peranan dalam hal ini.

e. Implementasi dan Penegakan

Konflik antara undang-undang yang mengatur kelautan dan daratan menimbulkan mandat yang saling tumpangtindih dan tanggung jawab yang tidak jelas. Tidak ada perlindungan hukum untuk spesies yang dilindungi yang berada diluar kawasan yang dilindungi. Terbatasnya hukum adat dan praktek yang ada untuk mengatur penggunaan sumber daya alam dan pelaksanaan pembatasan perdagangan satwa liar. Kuota legal yang diperbolehkan untuk panen spesies yang terdaftar di CITES tidak berdasarkan data ilmiah yang cukup dan tidak dikontrol dengan cukup. Lebih jauh lagi, kerangka hukum yang ada, khususnya di UU No.5 Tahun 1990, tidak mengakomodasi hukum adat atau praktek penduduk lokal dalam mengatur kepemilikan dan hak penggunaan sumber daya. 


\section{Kesimpulan}

Berdasarkan pemaparan hasil penelitian dan pembahasan dapat disimpulkan bahwa Upaya kerjasama internasional Pemerintah Indonesia dalam Penanganan Tingkat Perdagangan Satwa Liar di Indonesia tahun 2013-2016 telah dilakukakan beberapa upaya, antara lain melalui :

a. CITES yang merupakan payung perdagangan satwa liar. Di dalam konvensi CITES terdapat mandat yang harus dilakukan oleh setiap negara-negara anggota CITES yaitu dengan membuat regulasi nasional berkaitan dengan pencegahan perdagangan satwa liar ilegal, dan melakukan kerjasama dalam bentuk apapun baik secara regional atau juga kerjasama dengan pihak non-government.

b. ASEAN-WEN yaitu kerjasama di tingkat regional yang dilakukan oleh Indonesia dengan turut serta dan berperan aktif dalam ASEAN-WEN yang mengkoordinir aturan terhadap pelanggaran terhadap perdagangan satwa liar yang lebih fokus kepada perdagangan satwa liar darat..

c. Bentuk kerjasama lainnya yang dilakukan oleh pemerintah Indonesia adalah dengan membuat program-program khusus dengan lembaga-lembaga internasional seperti UNDP, USAID, GEF dan juga Organisasi internasional seperti WWF guna menekan tingkat perdagangan satwa liar. Beberapa program yang telah terwujud dan masih dilakukan sampai saat ini yaitu seperti program BIJAK (Bangung Indonesia untuk Jaga Alam demi Keberlanjutan) yang merupakan bentuk program kerjasama pemerintah Indonesia dengan Pemerintah Amerika melalui USAID dengan jangka waktu pelaksanaannya selama 5 tahun. Pemerintah Indonesia juga melakukan kerjasama dengan lembaga internasional lainnya seperti UNDP dan Global Environment Facility melalui program Proyek Sumatran Tiger.

Dengan upaya kerjasama tersebut yang dilakukan oleh pemerintah Indonesia dapat membantu menutupi kekurangan dan kendala-kendala yang dihadapi oleh pemerintah Indonesia perihal kurangnya sumber daya manusia dan juga sumber daya keuangan yang cukup besar untuk mengatasi praktek perdagangan satwa liar. 


\section{DAFTAR PUSTAKA}

Adi, W. P. (2017). Implementasi CITES (Convention on International Trade in Endangered Species of Wild Fauna and Flora) dalam Menangani Perdagangan Kukang Ilegal di Indonesia. Journal of International Relations, Vol 3, No 4, hal.21-31.

Aditya, D. (2016, Juni). Upaya Pemberantasan Perdagangan Hewan Ilegal di Indonesia Melalui Kerangka ASEAN WILDLIFE ENFORCEMENT NETWORK (ASEAN-WEN). Makassar.

Agustinova, D. E. (2015). Memahami Metode Penelitian Kualitatif : Teori Praktik. Yogyakarta: Calpulis.

Amelinda, M. (2013, Januari 17). Efektivitas Kegiatan Indonesia Dalam Kerjasama ASEANWILDLIFE ENFORCEMENT NETWORK (Reaksi Formal Dalam Menanggulangi Perdagangan Satwa Liar di Tingkat ASEAN). Depook, Jawa Barat.

Anna Santos., T. S. (2001). Do wildlife trade bans enhance or undermine conservation efforts? Applied Biodiversity Perspective Series. Applied Biodiversity Science, 1-15.

Apriwan. (2011). Teori Hijau: Alternatif dalam Perkembangan Teori Hubungan Internasional. Journal of International Studies, Multiversa.

Ardiaz, A. N. (2017, Desember). Apa yang dimaksud dengan Kerjasama Internasional. Retrieved Juli 23, 2018, from Dictio.id: https://www.dictio.id/t/apa-yang-dimaksud-dengan-kerjasamainternasional $/ 4622 / 2$

Aristides.Yoshua, P. F. (2016). PERLINDUNGAN SATWA LANGKA DI INDONESIA DARI PERSPEKTIF CONVENTION ON INTERNATIONAL TRADE IN ENDANGERED SPECIES OF FLORA AND FAUNA (CITES). Diponegoro Law Journal.

ASEAN. (n.d.). asean.org. Retrieved April 3, 2018, from http://asean.org/asean-socio-cultural/

ASEAN-WEN. (2011, January). Wildlife Law Enforcement Networking in Southeast Asia. Retrieved from https://www.slideserve.com/dana/wildlife-law-enforcement-networking-in-southeastasia-experiences-from-asean-wen

Atmasasmita, R. (2007). Ektradisi dalam Meningkatkan Kerja Sama Penegakan Hukum. Jurnal Hukum Internasional.

Baldwin, D. A. (1990). Theories of Internasional Cooperation Among Nation, Europe, America and Nontariff Barriers to Trade. Retrieved from https://books.google.co.id/books?id=q0BBDgAAQBAJ\&pg=PT161\&lpg=PT161\&dq=Joseph +Grieco,+1990,+Cooperation+Among+Nation+,+Europe,+America+and+Nontariff+Barriers +to+Trade,+Ithaca,+New+York:+Cornell+University+Press.\&source=bl\&ots=dcV71 KNI1T $\&$ sig $=\mathrm{Bq} 21-\mathrm{JOcPZn9R0}$

Batara, K. M. (2014, Maret 12). Eksistensi Convention On International Trade In Endangered Species of Wild Fauna and Flora (CITES) Terhadap Perlindungan Satwa Langka Dalam Menangani Perdagangan Bebas di Tingkat Internasional. Makassar.

Brian Hocking, \&. S. (1990). World Politics : An Introduction to International Relations. Harvester Wheatsheaf.

Bungin, M. B. (2007). Penelitian Kualitatif : Komunikasi, Ekonomi, Kebijakan Publik, dan Ilmu sosial Lainnya. Jakarta: Prenada Media Group. 
Cifebrima Suyastri, S. M. (2012). Mengukur Efektivitas CITES Dalam Menangani Perdagangan Satwa Liar Dengan Menggunakan Identifikasi Legalisasi Artikel CITES. Jurnal Transnasional, Vol 4, No.1.

CITES. (1976). Article Convention On International Trade in Endangered of Wild Fauna and FLora. CITES Article (pp. 256-258). Washington, D.C: cites.org.

CITES. (n.d.). List of Contracting Parties. Retrieved Mei 15, 2018, from Cites.org: https://www.cites.org/eng/disc/parties/chronolo.php

Citra Hennida, M. (2015). Rezim dan Organisasi Internasional. Malang: Intrans Publishing.

Documents, U. N. (1972, June). Declaration of the United Nations Conference on the Human Environment. Retrieved Juli 13, 2018, from Un-documents.net: http://www.undocuments.net/unchedec.htm

Duranes, J. (2016). Implementasi Convention On International Trade In Endangered Species (CITES) Dalam Upaya Konservasi Ramin Di Riau- Indonesia. eJournal Ilmu Hubungan Internasional, Volume 4, Nomor 4, 1177-1190.

Fernando, D. (2015). Pengaturan Perlindungan Satwa Langka Menurut Konvensi CITES Dan Implementasinya Di Indonesia. Jurnal Hukum Universitas Bung Hatta.

Freeland. (2015). Wildlife Enforcement Networks. Retrieved Juli 12, 2018, from www.freeland.org: http://www.freeland.org/programs/wens/

Greenpeace. (2018, Mei 2). Laporan Kerusakan Terumbu Karang Karimunjaya. Retrieved September 4, 2018, from greenpeace.org: http://www.greenpeace.org/seasia/id/press/reports/LaporanKerusakan-Terumbu-Karang-Karimunjawa/

Hanif, F. (2018, Juli 20). Upaya Kerjasama Internasional Pemerintah Indonesia terkait Penanganan Perdagangan Wildlife. (P. Kathrine, Interviewer)

Himawan, S. (2012, Oktober). Pemberantasan Wildlife Crime Di Indonesia Melalui Kerjasama ASEAN WILDLIFE ENFORCEMENT NETWORK (ASEAN-WEN). Semarang.

Indonesia, B. (2012, Juli 23). WWF umumkan negara pelanggar perdagangan satwa liar. Retrieved Maret 17, 2018, from www.bbc.com/indonesia: https://www.bbc.com/indonesia/majalah/2012/07/120723_wwf_satwa

Indonesia, W. (2005, Desember 16). WWF Indonesia. Retrieved Mei 22, 2018, from Pelaksanaan CITES di Indonesia: https://www.wwf.or.id/?4201/Pelaksanaan-CITES-di-Indonesia

Jafar, M. (2018, - -). KTT Lingkungan Hidup. Retrieved Oktober 8, 2018, from www.academia.edu: https://www.academia.edu/9514194/KTT_Lingkungan_Hidup

Jay, A. (2017, Januari 2). Green Political Theory. Retrieved April 3, 2018, from dictio.id: https://www.dictio.id/t/apa-yang-dimaksud-dengan-teori-politik-hijau-green-politicaltheory/5618

kemlu. (n.d.). Coral Triangle Initiative. Retrieved Juli 20, 2018, from Kemlu.go.id: https://www.kemlu.go.id/id/kebijakan/kerjasama-regional/Pages/CTI.aspx

Keraf, A. S. (2010). Etika Lingkungan Hidup. Jakarta: PT.Kompas Media Nusantara.

Kutilang. (1999). Peraturan Pemerintah Republik Indonesia Nomor 8 Tahun 1999. Retrieved Juli 20, 2018, from kutilang.or.id: http://www.kutilang.or.id/wpcontent/uploads/2011/07/PP_8_1999_tentang-Pemanfaatan-Jenis-Tumbuhan-dan-SatwaLiar.pdf 
Lyons, J. N. (2011). Wildlife laundering through breeding farms: Illegal harvest, population declines and a means of regulating the trade of green pythons (Morelia viridis) from Indonesia. Biological Conservation, Vol.44 (12)3073-3081.

maxmanroe. (2018). Pengertian Kerjasama: Manfaat, Beberapa Bentuk Kerjasama. Retrieved Juli 29, 2018, from maxmanroe.com: https://www.maxmanroe.com/pengertian-kerjasama.html

Maxmanroe. (2018). Pengertian Kerjasama: Manfaat, Beberapa Bentuk Kerjasama. Retrieved Juli 29, 2018, from maxmanroe.com: https://www.maxmanroe.com/pengertian-kerjasama.html

Nations, U. (1980, Januari 27). Vienna Convention on the law of treaties (with annex). Concluded at Vienna on 23 May 1969. Retrieved Juli 24, 2018, from treaties.un.org: https://treaties.un.org/doc/publication/unts/volume\%201155/volume-1155-i-18232english.pdf

Perwita, A. B. (2005). Pengantar Ilmu Hubungan Internasional. Bandung: PT. Remaja Rosdakarya.

Pfaltzfraff, J. E. (1997). Contending Theories International Relations : A Comprehensive Survey. Michigan: Longman.

ppid.menlhk. (2016, Juni 05). PIDATO KEMENLHK : SAMBUTAN MENTERI LINGKUNGAN HIDUP DAN KEHUTANAN PADA ACARA MEMPERINGATI HARI LINGKUNGAN HIDUP SEDUNIA. Retrieved September 07, 2018, from ppid.menlhk.go.id: http://ppid.menlhk.go.id/pidato_kemenlhk/browse/72

Prameswari, N. M. (2018). Dinamika Perdagangan Bilateral Indonesia - Jepang Selama Implementasi IJEPA. eJournal Ilmu Hubungan Internasional Fisip-Unmul, 3.

Prasetyo, D. A. (2012, Juni 2). Mengenal lebih dekat Coral Triangle Initiatives. Retrieved September 2, 2018, from marinescienceunpad.wordpress.com: https://marinescienceunpad.wordpress.com/2012/06/02/mengenal-lebih-dekat-coral-triangleinitiative-cti/

ProFauna. (2016, April 06). profauna.net. Retrieved Maret 28, 2018, from https://www.profauna.net/id/content/nilai-perdagangan-satwa-liar-triliunan-rupiah-profaunadesak-penegakan-hukum-yang-lebih\#.W1xaAdIzbcf

Purmono, A. (2016, Juni 5). Indonesia Rugi Rp. 9 Triliun Akibat Perdagangan Satwa Liar. Retrieved Maret 16, 2018, from Tempo.co: https://nasional.tempo.co/read/776900/indonesia-rugi-rp-9triliun-akibat-perdagangan-satwa-liar

Rahmad, R. (2015, Juni 27). Penegakan Hukum : Perdagangan Satwa Liar Dilindungi itu Terus Terjadi. Retrieved Oktober 8, 2018, from Mongabay.co.id: http://www.mongabay.co.id/2015/06/27/penegakan-hukum-perdagangan-satwa-liardilindungi-itu-terus-terjadi/

Ramadhani, M. (2015, agustus 07). Republika.co.id. Retrieved Juli 15, 2018, from https://www.republika.co.id/berita/internasional/global/15/08/07/nsp6w5366-pbb-setarakankejahatan-terhadap-satwa-liar-narkoba-dan-manusia

Renova, E. (2015). CITES. Retrieved Juli 24, 2018, from academia.edu: https://www.academia.edu/12340312/Convention_on_International_Trade_in_Endangered_S pecies_of_Wild_Fauna_and_Flora_CITES_

Secretariat, A. (2016). 2015 ASEAN SOCIO-CULTURAL COMMUNITY (ASCC SCORECARD). ASEAN Socio-Cultural Community. Kuala Lumpur: http://www.asean.org/storage/2016/04/9.March-2016-2015-ASCC-Scorecard-1.pdf. 
Semiadi, G. (2007). Pemanfaatan Satwa Liar dalam Rangka Konservasi dan Pemenuhan Gizi Masyarakat. Zoo Indonesia.

Services, D. O. (1980). Vienna Convention On The Law of Treaties. Retrieved from https://www.oas.org/legal/english/docs/Vienna\%20Convention\%20Treaties.htm

Shepherd, C. R. (2010). Illegal Primate Trade in Indonesia Exemplified by Surveys Carried Out over decade in North Sumatra. Endangered Species Research Vol. 11: 201-205, 202.

Soemarwoto, O. (2004). Ekologi, Lingkungan Hidup, Dan Pembangunan. Jakarta: Djambatan.

Sorensen, G. \&. (2014). Pengantar Studi Hubungan Internasional. New York: Pustaka Pelajar Offset.

Sugiyono. (2013). Metode Penelitian Kuantitatif, Kualitatif dan R\& D. Bandung: CV. Alfabesta.

Tiger, S. (2018, 07 30). Sumatrantiger.id. Retrieved from https://sumatrantiger.id/id/about-us/

Tim Harward, U. o. (1996). green political theory. Retrieved April 3, 2018, from http://www.psa.ac.uk/eps/1996/hayw.pdf

UNICRI. (1991). Environmental Crime. Retrieved Juli 2, 2018, from United Nations Interregional Crime and Justice Research Institute: http://www.unicri.it/topics/environmental/

Wildlife Conservation Society. (2015, Maret 6). Perdagangan Satwa Liar, Kejahatan Terhadap Satwa Liar dan Perlindungan Spesies di Indonesia : Konteks Kebijakan dan Hukum Changes For Justice Project. Retrieved 10 8, 2018, from USAID.gov: https://pdf.usaid.gov/pdf_docs/PA00KH51.pdf

Wiliam D Coplin, t. M. (1992). Pengantar Politik Intenasional: Suatu telaah teoritis. Bandung: CV Sinar Baaru.

WWF. (2013, Desember 26). 15 WWF Success Stories of 2013. Retrieved Juni 11, 2018, from worldwildlife.org: https://www.worldwildlife.org/stories/15-wwf-success-stories-of-2013

WWF. (2015). Celebrating Our Conservation Successes of 2015. Retrieved Juni 12, 2018, from worldwildlife.org: https://www.worldwildlife.org/stories/celebrating-our-conservationsuccesses-of-2015

WWF. (2016, Desember 01). Celebrating the Biggest Conservation wins of 2016. Retrieved Juni 12, 2018, from worldwildlife.org: https://www.worldwildlife.org/stories/celebrating-the-biggestconservation-wins-of-2016

Yani, A. A. (2005). Pengantar Hubungan Internasional. Bandung: PT. Remaja Rosdakarya.

Zacky. (2018, Maret 27). Deklarasi Stockholm 1972. Retrieved Juli 24, 2018, from ZonaReferensi.com: https://www.zonareferensi.com/deklarasi-stockholm-1972/ 